\title{
Diagnotic Support System of Melanoma based on Morphological Features
}

\author{
Toshiyuki Tanaka Member (Keio University, tanaka@appi.keio.ac.jp) \\ Reina Yamada Non-member (Keio University) \\ Michiko Tanaka Non-member (Keio University) \\ Kunio Shimizu Non-member (Keio University) \\ Masaru Tanaka Non-member (Keio University)
}

Keywords: melanoma, benign nevus, image processing, discriminant analysis

Melanoma is known as one of the most malignant and metastatic skin tumors. It is very difficult to distinguish melanoma from a benign nevus in its early stages, because of shape and color similarities. Since there are no objective measures for diagnosis, doctors have to subjectively diagnose melanoma and nevus. Therefore the accuracy of the diagnosis depends on the knowledge and experience that each doctor has accumulated. Although some researchers have proposed various measures of diagnosis, the measures are not so objective. In order to discriminate more accurately when melanoma is in its early stage, it is necessary for the doctor to clarify natures of tumors by objective and numerical evaluation that are helpful in diagnosis.

In this paper, we propose an objective method, which helps doctors to diagnose melanoma and benign nevus by numerical expression of features. We use images taken by dermoscope, and examples of melanoma and nevus are shown in Fig.1. First, we extracted the shape and contour of lesions from dermoscopy using image processing. Our proposed method extracted precise contour of lesioned region for most of used images. Successful contour extraction ratio reached 95\% (251 among 264 cases).

Figure 2 shows the contour extraction of lesioned region and major (and minor) axis of melanoma. Both a contour of lesioned region and dark intensity part are exaclty extracted with our method. This figure shows validness of our contour extraction method. Next, we computed 105 features based on ABCD-rule and evaluated them by F-test and t-test to examine whether each feature is efficient to use in discrimination of tumor. Next, we perform the stepwise method for searching some efficient features. The result of the stepwise method shows that the following ten features are valid for objective diagnosis.

(1) Laplacian deviation of contour

(2) Deviation of I component

(3) Minimum value of I component

(4) Minimum value of $a^{*}$ component

(5) Average of $b^{*}$ component

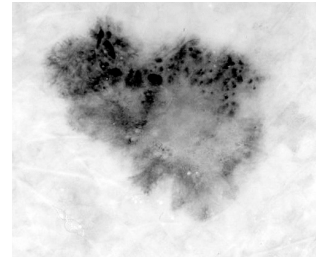

(a)

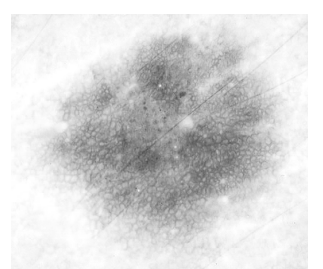

(b)
Fig. 1. Melanoma and benign nevus. (a) shows an example of melanoma, and (b) shows that of benign nevus.

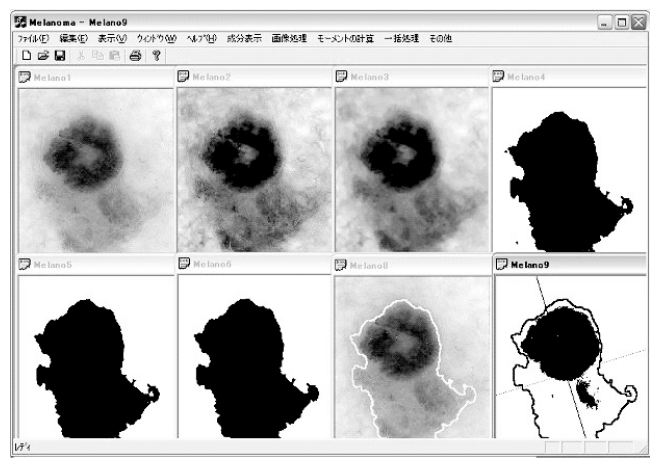

Fig. 2. An extractions of lesion area and features

(6) Color distribution with respect to minor axis

(7) Length of minor axis

(8) Length of major axis

(9) Distance between center of region and contour point

(10) Age of subject

Discriminant analysis using stepwise method showed an accuracy of $96.0 \%$, (Specificity of $98.3 \%$ and Sensitivity of $90.0 \%$ ), for a total of 251 lesions (70 Melanoma and 181 Benign Nevus). These results obviously showed that our proposed features, and this system are effective for objective diagnosis. 


\section{形態学的特徵量に基づく悪性黒色腫の診断支援システム}

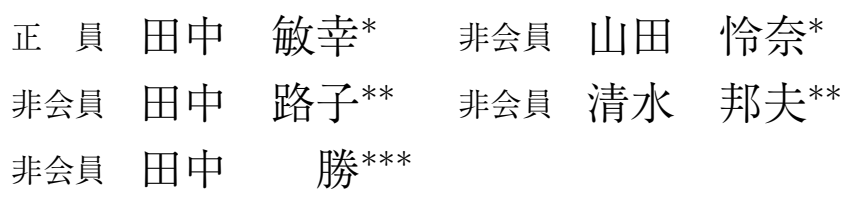

Diagnotic Support System of Melanoma based on Morphological Features

Toshiyuki Tanaka*, Member, Reina Yamada*, Non-member, Michiko Tanaka**, Non-member, Kunio Shimizu**, Non-member, Masaru Tanaka**, Non-member

At present the diagnosis of melanoma is mainly performed based on the experience of each doctor. They need some objective measure for diagnosis of melanoma and nevus. But there are few researches on index for the diagnosis. This study deals with features of melanoma and nevus for computer diagnosis. First, we extracted the contour of lesions by image processing. One hundred five values of features were computed based on ABCD-rule. Discriminant analysis showed the accuracy of $96.0 \%$ (Specificity of $98.3 \%$ and the Sensitivity of $90.0 \%$ ). The results obviously showed the difference between melanoma and nevus.

キーワード : 悪性黒色腫, 良性腫瘍, 画像処理, 判別分析

Keywords: melanoma, benign nevus, image processing, discriminant analysis

\section{1. はじめに}

皮膚表面に発生する皮膚癌（皮膚悪性腫瘍）には様々な 種類がある。悪性黒色腫は, それらの中でも最も悪性度の 高い腫瘍として知られている。悪性黒色腫は極めて転移し やすいため, 早期に発見し, 手術により病変領域部を大き く完全に除去する必要がある(1) (2)。悪性黒色腫の診断につ いては皮膚科医の間で診断基準を決めているが，抽象的な 表現による基準であるために各医師が主観的に診断を行っ ている。したがって, 鑑別がどの程度正確に行われたかは, その専門医に蓄積された知識に依存することになる。さら に，症例の中には，悪性黒色腫であるにもかかわらず良性 母斑に似た特徵をもつものや，逆に良性母斑のなかでも悪 性黒色腫に似た特徴をもつものが多く含まれる。そのため, ある程度以上症状が進行したものでなければ，正確な鑑別

\footnotetext{
*慶應義塾大学 理工学部 物理情報工学科

₹ 223-8522 横浜市港北区日吉 3-14-1

Faculty of Science and Technology, Keio University

3-14-1 Hiyoshi, Kohoku-ku, Yokohama 223-8522

** 慶應義塾大学 理工学部 数理科学科

于 223-8522 横浜市港北区日吉 3-14-1

Faculty of Science and Technology, Keio University

3-14-1 Hiyoshi, Kohoku-ku, Yokohama 223-8522

*** 慶應義塾大学 医学部 皮膚科学教室

₹ 160-8582 東京都新宿区信濃町 35

School of Medicine, Keio University

35 Shinanomachi, Shinjuku-ku, Tokyo 160-8582
}

が困難であることが多く，早期の段階で悪性黒色腫と良性 母玟を鑑別するのが難しいのが現状である。病変領域部分 を切り取り, 病理検査にまわすことによって早期に正確な 診断を行うことはできるが，切除することによって転移や 悪化を引き起こす恐れがあり, 皮膚科医の間ではあまり好 ましくない方法であると言われている。

現在, 悪性黒色腫の鑑別基準としては ABCD-rule, 7-point checklist, Pattern analysis, Menzies' scoring method など(3) が提案されており, 実際に医療の現場で 診断を行う皮膚科医は, それらの基準を用いて鑑別を行っ ている。先にも述べたとおり，これらの鑑別基準はどれも 医師の主観的評価を必要としており，十分な客観性をもっ ているとはいえない。早期鑑別やグレーゾーンにある症例 の鑑別をより正確に行うためには, 客観的かつ定量的な評 価によって, 悪性・良性を鑑別することが重要であると考 えられる。皮膚科医の間では, 客観的で定量的評価のでき る診断支援システムやスクリーニングシステムを望む声が 多くなっている。

近年，悪性黒色腫をはじめとする皮膚悪性腫瘍に関して 画像処理を用いた客観的診断のための研究 ${ }^{(4) \sim(14)}$ が行われ ている。その多くは病変境域の形状抽出法 (4) (7) やそれに 伴う画像の先鋭化, 毛髪除去 ${ }^{(6)}$ といった前処理技術の追求 が中心となっている。形状抽出の研究では, 比較的形状の はっきりしているものについては抽出が成功しているが, 輝 度情報を用いているため病変の周辺部に色の薄い部分があ 
る場合などには十分な形状抽出ができていない。これらの 研究の中には，形状抽出の結果をもとに悪性黒色腫と良性

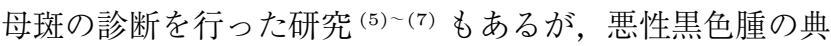
型的な症例のみを対象にしており，症例数も少ない。また， 形状特徵量やテクスチャ特徵の数值化を Expert System に よって行い, その数值をもとに診断を行った研究 ${ }^{(8) \sim(11)}$ が 報告されているが，悪性黒色腫と良性母玟で誤認識の可能 性の高い症例については除外している。マルチスペクトル カメラを用いた入力画像に対して形状特徵量とテクスチャ 特徵量を求めることにより悪性黒色腫の特有の特徵量を調 へようとした研究 ${ }^{(12)}$ もあるが，この研究においても悪性 黒色腫と良性母斑の種類を制限している。テクスチャ特徴

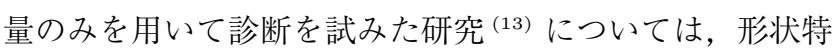
徵量を考慮した場合と比べて十分な鑑別精度が得られてい ない。病変の細胞組織画像をテクスチャ解析のみによって 診断を行った研究 ${ }^{(14)}$ などもあり, テクスチャ特徴量のみ でも有意差が現れることが示されているが，臨床的には初 期の診断時点では切除をしたくないという要望からこの手 法は臨床的診断支援やスクリーニングには利用できない。

本研究では, dermoscopy 画像を用いて, 悪性黒色腫と 母斑の客観的判別方法の検討・評価を行うことを目的とす る。なお初期診断における診断支援システムの構築が目標 であるので，皮膚表面の dermoscopy 画像を研究対象とす る。まず, dermoscopy 画像から病変領域を正確に抽出し, 皮膚科医が診断の際に重視する特徵の数值化を行い，特徴 量計算の際に必要な輪郭や長軸・短軸を求める。その後, 鑑 別基準の 1 つである $\mathrm{ABCD}$-rule に基づく特徴の数值化を 行い, それらの特徵量を評価して悪性・良性の判別に適し た特徴量や判別方法を検討・評価する。

\section{2. 腫瘍診断の方法}

$\langle 2 \cdot 1\rangle$ 腫瘍判別法の概要 まず，提案する腫瘍判別法 の概要について説明する。判別の方針としては，臨床医が 一般的に用いている ABCD-rule に基ついた数值化指標を 考えていくことにする。ABCD-rule は次のような判別基 準である。
A ：Asymmetry（非対称な形）
B：Border（辺縁がはっきりしない）
C：Color（不整でむらのある色調）
D : Diameter（直径 $6 \mathrm{~mm}$ 以上）

図 1 に悪性黒色腫と良性母斑の典型的な症例を示す。 ABCD-rule に照らし合わせると，図1(a) が悪性黒色腫で, (b) が良性母斑であることがわかる。

コンピュータ診断の前処理として 2 值化に用いる色成 分を決定し，コントラスト強調と Median Filteringによ る平滑化を行う。色成分については, RGB, YIQ, HVC, CIELab の 12 種類の色成分画像について比較・検討を行っ た。まず，悪性黒色腫および良性母斑について典型的な特 徵を持つと思われるものを 8 症例ずつ計 16 症例を皮膚科医 に選択してもらい，それぞれについて判別分析法に基づく

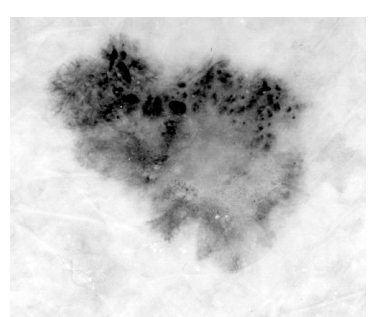

(a)

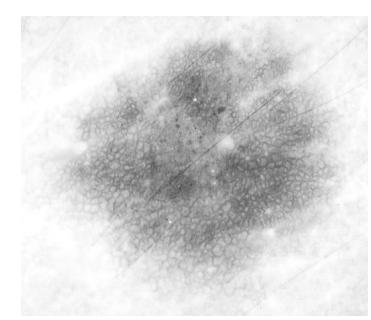

(b)
図 1 覀性黒色腫と良性母斑。(a) が悪性黒色腫, (b) が良性母玟の例

Fig. 1. Melanoma and benign nevus. (a) shows an example of melanoma, and (b) shows that of benign nevus.

2 值化を行った。2 值化した結果の図の形状が適当であるか どうかを皮膚科医に確認してもらい，それぞれの色成分に 基づく 2 值化結果について「精度よく抽出できた」「ある程 度の抽出ができた」「抽出が不完全だった」のいずれかを判 断してもらった。悪性黒色腫の画像, 良性母斑の画像とも に「精度よく抽出できた」という評価が最も多かった Blue 成分画像を解析に用いることにした。Median Filteringに よる平滑化の後, Laplacian Histogram 法と判別分析法を 組み合わせた 2 值化を行う。 2 值化後の画像にはノイズが 多く含まれ, 病変領域内で色の薄い部分の抽出精度が悪く なることが多い。そこで, 後処理として膨張・収縮処理, ノ イズとみなせる領域の除去, 病変領域の色補足を行う。さ らに病変について, 特徵量計算の際に必要な輪郭と長軸・ 短軸を求める。これらの抽出結果をもとにして，考えられ る形態学的特徽量を全て挙げ, 統計解析によって必要最低 限の形態学的特徵量の絞込みを行う。最終的に得られた特 徵量を利用して, 悪性黒色腫と良性母斑との判別を行う。

〈2・2〉 コントラスト強調本研究のために用意された 覀性黒色腫および良性母斑の画像は RGB 基底のディジタル 画像である。本研究では, 色成分による特徵量として, RGB 表色系だけでなくYIQ 表色系, HVC 表色系, CIELab 表 色系を用いている。RGB 表色系から YIQ 表色系および CIELab 表色系は, 輝度值の線形変換によって求めること ができる。また，HVC 表色系へは MTM 法（Mathematical Transform to Munsell) を用いて変換 ${ }^{(15)}$ を行うこと ができる。次に, 本研究で扱っている画像の濃度範囲は 0 255 なので，次式を用いたコントラスト強調を行っている。 ここで, 原画像のあるピクセルにおける輝度值を $z$, 原画 像の輝度值の最小值を $a$, 最大值を $b$ とする。また, 変換 後の輝度值を $z^{\prime}$, 変換後の輝度值の最小值を $a^{\prime}$, 最大值を $b^{\prime}$ とする。

$$
z^{\prime}=\frac{b^{\prime}-a^{\prime}}{b-a} \times(z-a)+a^{\prime}
$$

上式において, 本研究では $a^{\prime}, b^{\prime}$ の值としてそれぞれ $a^{\prime}=0$, $b^{\prime}=255$ を用いている。

〈2・3〉 Laplacian Histogram 法による 2 值化 dermoscopy 画像にはノイズが多く含まれる。ノイズの影響を 
減らすため, Median Filteringによる平滑化を行う。ここ で用いた Median Filtering は，注目画素を中心とした $3 \times$ 3 の領域内の 9 画素を濃度值の昇順（もしくは降順）に並 べ，その中央值（Median）を注目画素の濃度值とする処理 である。

dermoscopy 画像では対象物である病変領域が背景であ る皮膚に占める割合が小さい場合があり，この方法をその まま適用すると 2 クラスの分布の割合が極端に異なり，閯 值が大きいほうのクラスである背景側に偏ってしまう。そ こで，この問題を回避するために濃淡変化の大きい部分の みに注目して閾值を決定する必要がある。一般に濃淡変化 の存在するエッジの上部 (明るい側) と下部 (暗い側) では, Laplacian の絶対值が大きくなる ${ }^{(16)}$ 。画像のディジタル座 標 $(x, y)$ における輝度值を $f(x, y)$ とすると, Laplacian は 次式のように表すことができる。

$$
\begin{aligned}
\nabla^{2} f(x, y) & =\frac{\partial^{2} f(x, y)}{\partial x^{2}}+\frac{\partial^{2} f(x, y)}{\partial y^{2}} \\
& =f_{x x}(x, y)+f_{y y}(x, y) \cdots
\end{aligned}
$$

$$
\begin{aligned}
& f_{x x}(x, y) \\
& =f(x+1, y)-2 f(x, y)+f(x-1, y) \cdots \\
& f_{y y}(x, y) \\
& =f(x, y+1)-2 f(x, y)+f(x, y-1) \cdots
\end{aligned}
$$

原画像に対して Laplacian の演算を行い，大きな值をも つ画素を全画素の $10 \%$ だけ抽出する。全画素の何％を抽出 するかによって結果が代わることも考えられるが，ここで は Laplacian Histogram 法において一般的に用いられてい る $10 \%$ 抽出を採用することにした。これらの画素について 輝度ヒストグラムを計算すると，その分布はエッジの上部 および下部の濃淡レベルに対応する 2 つのピークをもつと 考えられる。この双峰型のヒストグラムから䦨值を自動決 定する手法を Laplacian Histogram 法と呼んでいる。ヒス トグラムから閾值を求める具体的な手法としては，判別分 析法がしばしば使用される。判別分析法は, 画像の濃度ヒ ストグラムを 2 クラスに分け，そのクラス間分散が最大に なるような閾值を求める方法である。 $k$ を閾值として画像 の全分散 $\sigma_{T}^{2}$ とクラス間分散 $\sigma_{B}^{2}$ を求め, 判別分析で用い られる次の基準 (クラスの分離度) を用いて $k$ を評価する。

$$
\eta=\frac{\sigma_{B}}{\sigma_{T}}
$$

本研究では, 上式の $\eta$ の值を最大とする $k$ を最適閾值 ${ }^{(19)}$ とする。ここまでの処理で, 原画像の 2 值化を行うことが できる。

$\langle\mathbf{2} \cdot \mathbf{4}\rangle$ 病変部の輪郭抽出 ある程度以上の大きさの ノイズは, Median Filtering では除去できない。また，病 変内部の色が薄い場合には 2 值化によって背景領域とされ 病変領域中に穴があいてしまう場合がある。それらは 2 值 化を行った後でもノイズとして残ってしまう。これらのノ
イズを除去するために，まず画像全体でラベリングを行い， それぞれの面積を求める。本研究では, 画像あたりの抽出 対象とする領域（病変領域）は 1 つなので, 最大の面積を もつもの以外をノイズとみなし，背景領域と併合する。膨 張と収縮を組み合わせることによって，図形の細かい凹凸 や溝の検出あるいは除去が可能となる。

膨張・収縮処理を行った後で, 病変領域の輪郭を求める ためにテンプレート・マッチングによる輪郭抽出を行う。こ こでは Prewittの方法を用いてテンプレート・マッチング を行う。Prewittの方法では，エッジの方向に対する 8 種 類のマスクを用意する。入力画像の画素とその周囲の画素 にマスクの相関を取ることでエッジの方向を求めている。

$\langle 2 \cdot 5\rangle$ 病変形状の長軸・短軸の抽出 悪性黒色腫の特 徵の 1 つに形状の非対称性がある。そこで病変領域の輪郭 をもとに, 対称軸 (長軸・短軸) を求める。対称軸を求め る方法としては, 2 次モーメントを用いる方法を利用する。 画像中の病変部分の重心を $\left(i_{g}, j_{g}\right), x$ 軸, $y$ 軸の 2 次モー メントを $\mu_{02}, \mu_{20}, \mu_{11}$ とした時, 重心を通る慣性主軸の傾 き $\theta$ は次式のように表すことができる。

$$
\theta=\frac{1}{2} \tan ^{-1}\left\{\frac{2 \mu_{11}}{\mu_{20}-\mu_{02}}\right\}
$$

この $\theta$ を用いて長軸，短軸は以下のように求められる。

$$
\begin{aligned}
& y=\tan \theta\left(x-i_{g}\right)+j_{g} \cdots \\
& y=-\frac{1}{\tan \theta}\left(x-i_{g}\right)+j_{g}
\end{aligned}
$$

$\langle 2 \cdot 6\rangle$ 悪性黒色腫と母斑の特徵量 本研究では悪性 黒色腫および良性母斑を表す特徴として, ABCD-ruleに 基づく 105 個の特徵量の計算を行う。次に本研究で用いた ABCD-rule に対応する特徵量について概要を記述する。

(1) Asymmetry（非対称な形）

悪性黒色腫には良性母斑に比べて, 形状が非対称という 特徵がある。そこで, 長軸, 短軸に対する輪郭の対称性を 利用して特徵量を数值化する。また，覀性黒色腫には，形 状や色の分布が非対称という特徵があるため, 病変領域を 長軸・短軸を用いて 4 分割して, 各領域における面積・色 の濃い部分の面積・輪郭の Gradient の平均と分散・輪郭の Laplacian $(3 \times 3$ mask, $5 \times 5$ mask $)$ の平均と分散・重 心から輪郭までの距離の平均と分散の值によって数值化を 行っている。病変領域内は一様な輝度值ではなく, 場所に よって輝度值が異なっている。上記の色の濃い部分という のは, 病変領域内で 2 值化を行った際の輝度值 0 の部分の ことを意味している。本研究では, Asymmetryについて 12 個の特徴量を検討する。

(2) Border（辺縁がはっきりしない)

悪性黒色腫の特徵である輪郭のあいまいさを数值化する。 病変領域の輪郭付近での色の変化を数值化するため, 輪郭 上の点での Gradient と Laplacian $(3 \times 3$ mask, $5 \times 5$ mask）の值を計算し, その最大值 · 最小值 ·平均 ·分散 · 偏差を特徴量として求める。本研究では, Borderに関して 
15 個の特徵量を検討する。

(3) Color (不整でむらのある色調)

悪性黒色腫には，色の濃淡変化がなだらかでなく偏りが あるという特徵がある。一方，良性母斑は色の濃淡変化が なだらかで極端な偏りが見られない。色の分布を数值化す る際，病変領域内のどの色成分を用いるかを検討する必要 がある。本研究では，病変領域抽出の際に用いた色成分と同 様にBlue 成分を利用することとする。まず，病変領域内で Blue 成分を用いた 2 值化を行う。 2 值化には，病変領域抽 出処理と同様に Laplacian Histogram 法と判別分析法を組 み合わせた方法を用いる。この色むらが均等に分布してい るか, 偏っているかを特徵量として求める。前述した病変領 域の中で Blue 成分領域の重心と病変領域の重心との距離を 求める。病变領域抽出の際に利用した RGB, YIQ, HVC, CIELab 各色成分の最大值 ·最小值 ·平均 ·分散 ·偏差を計 算する。なお，これらの特徵量の計算に関しては，各色成 分に対して色情報を変えてしまうような Median Filtering による平滑化やコントラスト強調などの処理は行わない。 本研究では, Color に関する 66 個の特徴量を検討する。

(4) Diameter (直径 $6 \mathrm{~mm}$ 以上)

悪性黒色腫は，急速に成長するため形状が大きいものが 多い。特に $6 \mathrm{~mm}$ 以上の皮膚病変は, 悪性の確率が高いと 言われている。そこで，病変領域抽出の際に求めた長軸・ 短軸を用いて，病変の長径・短径を計算する。物体の形状 を示す代表的な特徴量として，重心，面積，周囲長，円形 度があげられる。これらの特徵量を以下に示す ${ }^{(17)}$ 。

重 心：物体に含まれる画素の平均位置

面 積：連結成分内の画素数

周囲長： 輪郭追跡によって求めた輪郭線の画素数

円形度：面積を $S$, 周囲長を $L$ として, 円形度 $e$ をつぎ のように定義する。

$$
e=\frac{4 \pi S}{L^{2}}
$$

また，悪性黒色腫は良性母斑に比べ形状がいびつで大き い場合が多い。本研究では，病変領域の重心から各輪郭点 までの距離の最大值・最小值・平均・分散・偏差も検討の 対象とする。本研究では, Diameter に関する 10 個の特徴 量について検討する。

上述のように ABCD-rule に基づいた 103 個の特徵量に 年齢と性別を数值化したものを特徴量として加えて, 計 105 個の特徵量について腫瘍判別アルゴリズムの検討を行う。

$\langle\mathbf{2 \cdot 7}\rangle$ 特徵量の統計解析 ここでは, 考察の対象と した 105 個の特徵量について, 客観的判別方法への特徴量 として適当かどうかの検定を行う。本研究で用いている標 本は悪性黒色腫と良性母斑であるので，互いに独立な標本 である。また，各特徴量については正規分布が仮定できる ものとする。そのような仮定のもとで各特徵量の有意性を 評価するため, 105 個全ての特徵量に対し F 検定を行う。 $\mathrm{F}$ 検定は有意水準 $\alpha=0.05$ を用いて衰却を行う。

$\mathrm{F}$ 検定の結果，等分散性が認められる場合には平均值に
表 1 悪性黒色腫と母斑のサンプル数

Table 1. Sample Number of Melanoma and Nevus

\begin{tabular}{l|l|r}
\hline \multirow{3}{*}{ Melanoma } & Melanoma less than 0.75mm & 36 \\
& Melanoma 0.76-1.5mm & 11 \\
& Melanoma more than 1.5mm & 6 \\
& Melanoma in situ & 23 \\
\hline Nevus & Clark nevus & 188 \\
\hline
\end{tabular}

対して標準的な $\mathrm{t}$ 検定を行い，等分散性が認められない場 合には平均值に対してWelchの $\mathrm{t}$ 検定を行う。 $\mathrm{t}$ 検定につ いても有意水準 $\alpha=0.05$ を用いて棄却を行う。t 検定に よって優位性の認められた特徴量についてのみ次に判別分 析を行う。

$\mathrm{t}$ 検定によって選別された特徴量について，全症例を用 いた分類および Cross-validation（Leave-one-out 法）に よる分類の 2 種類の方法を行う。Cross-validation という のは，標本の中の 1 つを任意に選び，その 1 つを未知サン プル，それ以外を既知のデータとして，未知サンプルがど のように分類されるかを調べる方法である。標本の 1 つず つを未知サンプルにすれば少ない標本数でも精度のよい判 別分析を行うことができる。

本研究ではまず全症例を用いて有効な独立変数の選択を 行う。105の全特徴量を用いてに対して $\mathrm{F}$ 検定と $\mathrm{t}$ 検定を 行って有意差のある特徵量を選ぶ。次に有意差のある特徴 量に対して, Stepwise 法を用いて有効な特徵量を選択す る。Stepwise 法は独立変数の候補の中から判別率をよくし ている少数の独立变数を選ぶ際によく用いられる方法であ る。選ばれた独立变数を用いて全症例に対する腫瘍鑑別と Cross-validation による腫瘍鑑別について比較を行う。

〈2・8〉腫瘍判別実験本研究では, Dermoscopy of Pigmented Skin Lesions ${ }^{(18)}$ に添付された Interactive Atlas of Dermoscopy の CD-ROM『DERMOSCOPY an interactive atlas』に収録された悪性黒色腫および良性母斑 の dermoscopy 画像を用いた。これらの画像は, Heine 社 の DermaPhotoにより倍率 10 倍で撮影されたものである。 本研究で用いた画像数を表 1 に示す。また, 画像の解像度 は 30 pixels $/ \mathrm{mm}$ としている。本研究では, 表 1 に示すよ うに悪性黒色腫 76 症例と良性母斑 188 症例の dermoscopy 画像から病变領域の抽出を行い, 特徴量の計算を行い, 提 案する腫瘍判別法について検討する。

\section{3. 結 果}

提案する腫瘍判別アルゴリズムを用いて病変領域を抽出 した結果を図 3 に示す。図 3 の (a),(d) はそれぞれ悪性黒 色腫と良性母斑の原画像である。図の (b),(e) は皮膚科医 によって抽出された腫瘍領域, (c),(f) は本手法によって自 動的に抽出された腫瘍領域を表す。本手法によって得られ た領域抽出結果を皮膚科医が確認したところ十分な形状が 得られていることが認められた。本研究により得られる領 域抽出結果と特徵量計算のために必要な情報抽出結果を図 


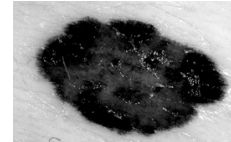

(a)

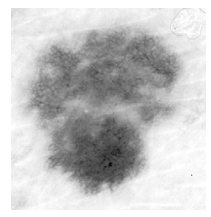

(d)

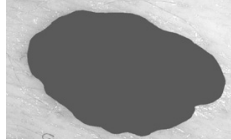

(b)

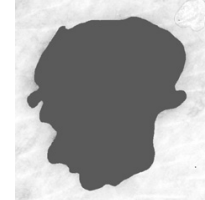

(e)

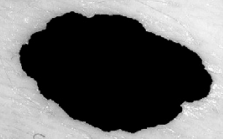

(c)

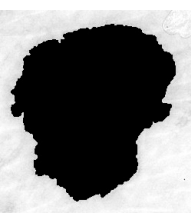

(f)
図 2 皮膚科医による領域指定と領域抽出法によ る結果。(a),(d) は原画像，(b),(e) は医師による 領域抽出, (c),(f) は提案法による領域抽出結果。 Fig. 2. The lesion area obtained by dermatologists and our system. (a),(d) are the original images, (b),(e) are the area by dermatologist, and (c),(f) are the area obtatined by our system.

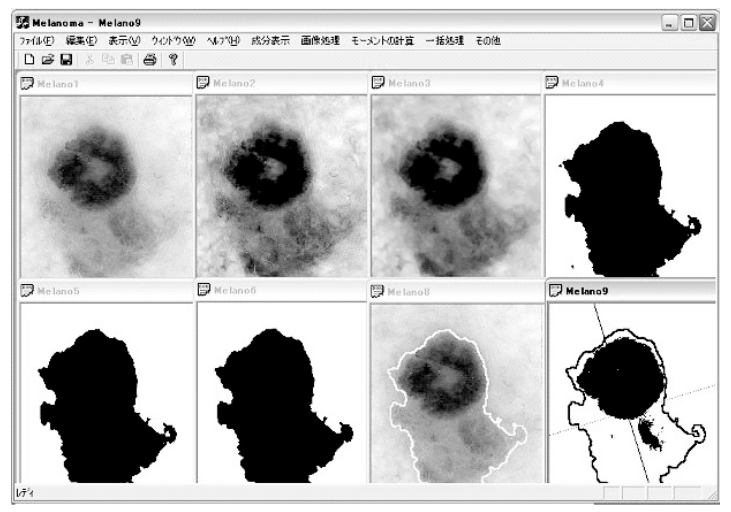

図 3 腫瘍領域と特徵量の抽出

Fig. 3. An extractions of lesion area and features

3 に示す。図 3 の上段左から，腫瘍の原画像，コントラス 卜強調後の Blue 成分画像, Median Filtering 後の画像, 2 值化画像, 下段左から，ノイズ除去後の画像，色補足後の 穴埋め画像, 原画像と輪郭の重ね合わせ画像, 長軸 · 短軸 計算後の画像をそれぞれ表している。研究に用いた 264 症 例のうち大部分については，原画像からこれらの情報が正 確に得られていることが確認されている。しかし, 皮膚領 域と病変領域の境界が不明瞭な場合や病変内での濃度差が 大きい場合において, 病変として必要な領域の一部だけし か抽出できないことがあった。本システムでは，ある程度 の濃度差がある領域の抽出は可能であるが, 濃度差が少な い領域の正確な抽出は困難であった。

病変領域抽出結果を用いて，ABCD-rule に基づく 105 個の特徵量により統計解析をした。結果の一例として病変 領域内でI 成分の分散について計算した結果を図 3 および 図 3 に示す。図 3 は医師が選んだ典型的な形状特徵を持つ 17 症例に対する解析結果, 図 3 は本研究で使用した全て の画像に対する解析結果である。図 3 を見てわかるとおり, 典型的な形状特徵をもつ悪性黒色腫と良性母玟については,

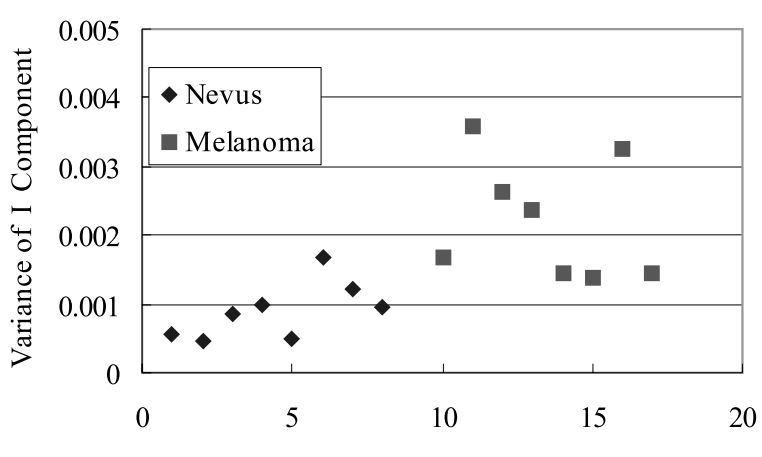

Subject

図 4 I 成分による典型的な形状特徴をもつ症例 の判別結果

Fig. 4. Discriminant analysis with I component for typical shape cases

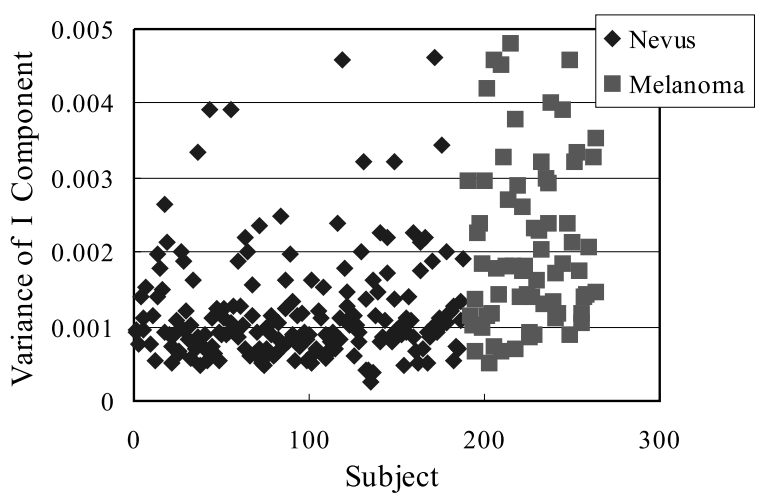

図 5 I 成分による全症例の判別結果

Fig. 5. Discriminant analysis with I component for all the cases

病変領域内での I 成分の分散の閾值を 0.014 とすることに よって，ある程度の判別を行うことができた。研究で使用 した全ての画像に対して同様の計算を行った図 4 において は, 覀性黒色腫の值は比較的広い範囲に分布しているのに 対し, 良性母斑は狭い範囲での分布となった。また，良性 母玟の大部分が典型的な特徵をもつ症例での結果と同様に 0.014 以下の值となっている。

$\mathrm{F}$ 検定により等分散性を検定し，その結果をもとに $\mathrm{t}$ 検 定を行ったところ，105の特徵量のうち 63 の特徴量で有意 差が確認できた。さらに 63 個の特徴量に対して Stepwise 法を用いて特徵量の絞込みを行った。その結果, つぎの 10 個の特徵量が腫瘍判別に有効であることがわかった。

(1) 輪郭の Laplacian 偏差

(2) YIQ 基底画像の I 成分の偏差

(3) YIQ 基底画像の I 成分の最小値

(4) CIELab 基底画像の $\mathrm{a}$ *成分の最小值

(5) CIELab 基底画像の $\mathrm{b}^{*}$ 成分の平均值

（6）短軸を基準にした Blue 成分のモーメント

（7）腫瘍形状の短径

（8）腫瘍形状の長径 
表 210 個の特徵量による腫瘍判別分析

Table 2. Discriminant analysis of tumors using 10 features

\begin{tabular}{l|c|c|c|c}
\hline \multicolumn{2}{c|}{} & \multicolumn{2}{|c|}{ Results of Discrimination } & \multirow{2}{*}{} \\
\cline { 3 - 4 } \multicolumn{2}{c|}{} & Clark Nevus & Melanoma & \\
\hline \multirow{2}{*}{ By doctor } & Clark Nevus & 178 & 3 & $98.3 \%$ \\
\cline { 2 - 4 } & Melanoma & 7 & 63 & $90.0 \%$ \\
\hline
\end{tabular}

表 3 Cross-validation による腫瘍判別分析

Table 3. Discrimination of tumors using Crossvalidation method

\begin{tabular}{l|c|c|c|c}
\hline \multicolumn{2}{c|}{} & \multicolumn{2}{|c|}{ Results of Discrimination } & \multirow{2}{*}{} \\
\cline { 3 - 4 } \multicolumn{2}{c|}{} & Clark Nevus & Melanoma & \\
\hline \multirow{2}{*}{ By doctor } & Clark Nevus & 174 & 7 & $96.1 \%$ \\
\cline { 2 - 5 } & Melanoma & 10 & 60 & $85.7 \%$ \\
\hline
\end{tabular}

（9）中心からの距離 D の平均

（10）年齢

Stepwise 法によって得られた 10 個の特徵量を用いて，全 症例に対して判別分析を行った結果を表 3 に示す。全症例を 判別した結果は, Specificity 98.3\%, Sensitivity 90.0\%, 判 別率 96.0\%であった。また, Cross-validation (Leave-oneout 法)による判別分析を行った結果を表 3 に示す。Crossvalidation では, Specificity 96.1\%, Sensitivity 85.7\%, 判別率 $93.2 \%$ であった。本研究では全症例を用いた判別分 析を行っているため，全ての画像を用いたときに最も精度 よく分類が行われるように判別モデルが作られている。そ のため新たな症例に対して鑑別を行う場合に必ずしも表 3 の鑑別率を得ることはできない。Cross-validation では 1 つの症例を除いて判別モデルを作り，腫瘍鑑別を行ってい るため，全症例を用いた場合よりは鑑別率が下がるが，新 たな症例に対しても同様の鑑別率が期待できる。現時点で は，形状と色分布のみを特徴量としていることを考えると 十分に精度のよい結果が得られている。

\section{4. 検討}

本研究では腫瘍の形状から得られる特徵量によって判別 を行っているため, 形状抽出の精度が結果に直接の影響を及 ぼししまう。医師に確認をしてもらったところほほ正確に 抽出ができているが，全症例中の 13 症例（悪性黒色腫 6 症 例，良性母斑 7 症例）については正しい形状が得られなかっ た。形状抽出に失敗した例を図 4 に示す。図の (a),(b),(c) が悪性黒色腫，(d),(e),(f) が良性母斑をあらわす。医師が 領域指定した (b),(e) と提案法による領域抽出結果 (c), (f) に大きな差がある。悪性黒色腫と良性母斑両方において， White scar-like area あるいは Hypo-pigmentation と呼 ばれる色の薄い部分（白っぽい部分）を持つ場合がある。 White scar-like area というのは悪性黒色腫に特有の薄白 色領域であり, Hypo-pigmentation は色素沈着領域内に見 られる脱色領域である。色の薄い部分を皮膚領域としてし まう本手法では，このような領域を含む症例では形状を精

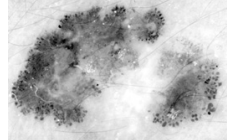

(a)

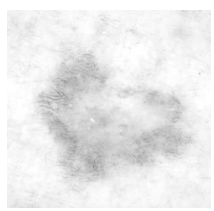

(d)

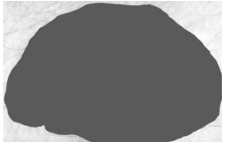

(b)

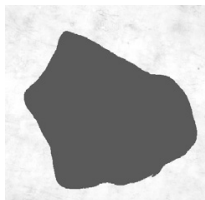

(e)

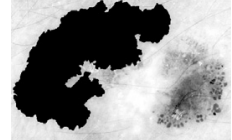

(c)

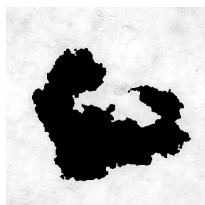

(f)
図 6 形状抽出に失敗した症例。上段が悪性黒色 腫，下段が良性母斑に対する結果。(a),(d) は原画 像，(b),(e) は医師による領域抽出, (c),(f) は提 案法による領域抽出結果。

Fig. 6. Case of failure in shape extraction method. Figures in upper stage corresponds to melanoma, those in lower stage corresponds to benign nevus. Figure (a),(d) are the original images, (b), (e) are the area by dermatologist, and (c),(f) are the area obtatined by our system.

度よく抽出することができない。本研究では，このように 形状抽出に失敗した症例についてはその後の判別分析を行 わないことにした。診断支援システムでは, 画像入力から 腫瘍鑑別までを自動的に行うことを目的としているので, 形状が精度よく抽出できなくてもその後の鑑別が行われて しまう。したがってこのような形状抽出の失敗を防ぐこと が今後の課題となる。

また，本手法による悪性黒色腫の判別率は $90 \%$ 超える ものであるが，それでも数\%の誤判別が行われている。本 研究では形状特徴量および濃色の分布から判別を行ってい るが, 臨床的にはそれ以外にDOTS と呼ばれる悪性黒色腫 特有の色素構造物や特有の色成分などによって判別が行わ れている。残りの数\%については，そのような悪性黒色腫 特有の特徵量の数值化を行っていかなければ, 判別精度を 上げることはできないものと思われる。しかし, 現時点で は DOTS の抽出や有効な数值化そのものが困難であるた め DOTS や特有色によって判別率がどの程度変わるかを 議論することができない。また，皮膚表面からの検査だけ でなく病理検査を行わなければ $100 \%$ の鑑別結果は得られ ないという医師の意見もあるので，最終的にどのような特 徵量が残りの数\%に対して有効かを調べることは今後の研 究課題としたい。

\section{5. まとめ}

本論文では，画像処理の手法を用いて悪性黒色腫と良性 母玟の特徵を客観的かつ定量的な数值として求め, 診断支 援となる客観的判別方法について報告する。悪性黒色腫と 良性母斑の特徴の違いを検討し, ABCD-rule に基づいて 特徵を数值化することとした。まず病変領域抽出システム を作成し, 悪性黒色腫と良性母斑の dermoscopy 画像から 
病変領域抽出実験を行った。Blue 成分画像を用いた 2 值 化の結果，全画像の $95.8 \%$ の病変領域の抽出ができた。提 案法では，悪性黒色腫と良性母玟の領域境界がある程度の 強度をもっている場合に，領域を抽出することが可能であ ることが確認できた。次に，輪郭および長軸・短軸を求め， ABCD-rule に基づく特徵の指標として 105 個の特徵量を 提案し, 本システムによる病変領域抽出結果をもとにそれ ぞれの特徴の分布を求めた。これらの指標により悪性黒色 腫および良性母斑の特徵を客観的かつ定量的に表すことが 可能であると確認できた。さらに，分類方法を検討し，判別 分析を試みたところ，Stepwise 法で選択された 10 個の特 徵量による判別モデルにより，251 症例（悪性黒色腫 70 症 例，良性母斑 181 症例）の画像における判別率は $96.0 \%$ と なった。本アルゴリズムは診断に有効な客観的判別方法と して応用できると考えられる。

(平成 18 年 2 月 28 日受付，平成 18 年 8 月 30 日再受付)

\section{文献}

（1）西山茂夫・西川武二・西岡 清：「皮虐科検査法ハンドブック」，南 江堂, pp.413-417 (1991)

（2）小川秀興・新村眞人：「TEXT 皮膚科学」, 南山堂, pp.277-281 (1998)

(3) "Diagnostic Algorithms for Differentiating Benign Melanocytic Lesions from Melanoma", http://www.dermoscopy.org/ cnmd/3-UC-2.htmla

(4) J. Chen, R. Joe Stanley, R.H.Moss, and W.V. Stoecker: "Colour analysis of skin lesion regions for melanoma discrimination in clinical images", Skin Research and Technology, Vol.9, No.2, pp.94-104 (2003-2)

(5) R. Yamada, T. Tanaka, M. Tanaka, and S. Kobayashi: "Pathological Feature Evaluation of Melanoma by Image Processing", Proceedings of the International Federation for Medical \& Biological Engineering EMBEC'02 Part2, pp.930$931(2002)$

(6) H. Ganster, A. Pinz, R. Röhrer, E. Wilding, M. Binder, and H. Kittler: "Automated Melanoma Recognition", IEEE Trans. Medical Imaging, Vol.20, No.3, pp.233-239 (2001-3)

( 7 ) O. Colot, R. Devinoy, A. Spmbo, and D. de Brucq: "A Colour Image Processing Method for Melanoma Detection", Lecture Notes in Computer Science Vol.1496, pp.562-569 (1998)

(8) P. Rubegni, M. Burroni, G. Cevenini, R. Perotti, G. Dell'Eva, P. Barbini, M. Fimiani, and L. Andreassi: "Digital Dermoscopy Analysis and Artificial Neural Network for Differentiation of Clinically Atypical Pigmented Skin Lesions : A Retrospective Study", J. Invest. Dermatol., Vol.119, No.2, pp.471-474 (2002-2)

(9) P. Rubegni, A. Ferrari, G. Cevenini, D. Piccolo, M. Burroni, R. Perotti, K. Peris, P. Taddeucci, M. Biagioli, G. Dell'Eva, S. Chimenti, and L. Andreassi: "Differentiation between pigmented Spitz nevus and melanoma by digital dermoscopy and stepwise logistic discriminant analysis", Melanoma research, Vol.11, pp.37-44 (2001)

(10) P. Rubegni, G. Cevenini, M. Burroni, R. Perotti, G. Dell'Eva, P. Sbano, C. Miracco, P. Luzi, P. Tosi, P. Barbini, and L. Andreassi: "Automated diagnosis of pigmented skin lesions", International Journal of Cancer, Vol.101, No6, pp.576-580 (2002-6)

(11) L. Andreassi, R. Perotti, P. Rubegni, M. Burroni, G. Cevenini, M. Biagioli, P. Taddeucci, G. Dell'Eva and P. Barbnini: "Digital Dermoscopy Analysis for the Differentiation of Atypical Nevi and Early Melanoma: A New Quantitative Semiology", Arch. Dermatol., Vol.135, No.12, pp.14591465 (1999-12)

(12) M. Elbaum, A.W. Kopf, H.S. Rabinovitz, R.G.B. Langley, H. Kamino, M.C. Mihm, A.J. Sober, G.L. Peck, A. Bog- dan, D.G.-krusin, M. Greenebaum, S. Keem, M. Oliviero, and S. Wang: "Automatic differentiation of melanoma from melanocytic nevi with multispectral digital dermoscopy : A feasibility study", J. Am. Acad. Dermatol., Vol.44, No.2, pp.207-218 (2001-2)

13) A. Murali, W.V. Stoecker, and R.H. Moss: "Detection of solid pigment in dermatoscopy images using texture analysis", Skin Research and Technology 2000, pp.193-198 (2000)

(14) M. Wiltgen, A. Gerger, and J. Smolle: "Tissue counter analysis of benign common nevi and malignant melanoma", International Journal of Medical Informatics, Vol.69, pp.17-28 (2003)

15) M. Miyahara and Y. Yoshida: "Mathematical transform of ( R, G, B) color data to munsell $(\mathrm{H}, \mathrm{V}, \mathrm{C})$ color data, The Journal of The Institute of Television Engineers of Japan, Vol.43, No.10, pp.1129-1136 (1989-10) (in Japanese) 宮原 誠・吉田育弘:「色デー夕 $(\mathrm{R}, \mathrm{G}, \mathrm{B}) \Leftrightarrow(\mathrm{H}, \mathrm{V}, \mathrm{C})$ 数学的 変換方法」, テレビジョン学会誌, 43, 10,pp.1129-1136 (1989-10)

(16) J.S. Weszka, R.N. Nagel, and A. Rosenfeld: "A Threshold Selection Technique", IEEE Trans. Computers, pp.1322-1326 (1974)

(17） 井上誠喜 -八木伸行 - 林 正樹 - 中須英輔 · 三谷公二 - 奥井誠人： 「C 言語で学ぶ実践画像処理」, オーム社 (1999)

(18) H.P. Soyer, G. Argenziano, S. Chimenti, S.W. Menzies, H. Pehamberger, H.S. Rabinovitz, W. Stolz, and A.W. Kopf: "DERMOSCOPY of PIGMENTED SKIN LESIONS", Medical Publishing \& New Media (2001)

19) N. Ohtsu: 'An Automatic Threshold Selection Method Based on Discriminat and Least Squares Criteria', The Transactions of the Institute of Electronics and Communication Engineerings of Japan, Vol.J63-D, No.4, pp.349-356 (1980-4) (in Japanese)

大津展之:「判別および最小 2 乗基準に準づく自動しきい值選定法」, 通学論, J63-D, 4, pp.349-356 (1980-4)

田 中 敏 幸 (正員) 1960 年生。1982 年 3 月慶應義塾大学工

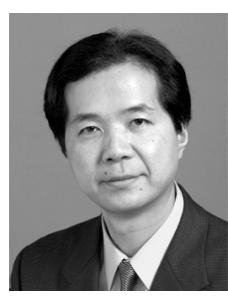
学部計測工学科卒業。1989 年 3 月同大学大学院 理工学研究科博士課程計測工学専攻修了。工学博 士。同年 4 月慶應義塾大学理工学部計測工学科助 手。1993 年専任講師。1995 年〜1996 年ドイッ. アーヘン工科大学客員研究員。同年 4 月慶應義塾 大学理工学部物理情報工学科専任講師。2003 年 4 月助教授。現在に至る。医用画像処理，バイオ メトリクス認証, GPS とその応用, 音声信号処理, 非線形振動論の研 究に従事。電子情報通信学会, 計測自動制御学会, IEEE, ION, 日 本生体医工学会などの会員。

山 田 怜 奈 （非会員） 2002 年 3 月慶應義塾大学理工学部物

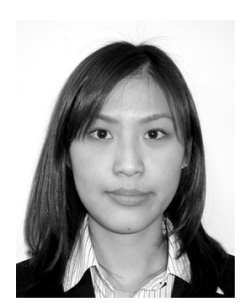
理情報工学科卒業。2004 年 3 月同大学大学院理 工学研究科修士課程修了。大学学部，大学院を通 じて悪性黒色腫のコンピュー夕診断に関する研究 に従事。2004 年 4 月野村総合研究所入所。現在 に至る。

田 中 路 子 (非会員) 2002 年 3 月慶應義塾大学理工学部数理

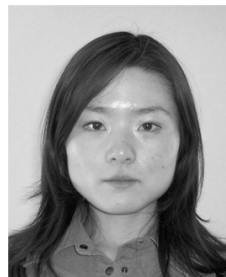
科学科卒業。2004 年 3 月同大学大学院理工学研究 科修士課程修了。在学中に統計的手法を用いた悪 性黒色腫と良性母斑の診断法の研究に従事。現在, アイエヌジー生命保険（株) (ING Life Insurance Company, Ltd.) に勤務。 
清 水 邦夫 (非会員) 1972 年 3 月東京理科大学理学部応用 数学科卒業。1976 年 3 月同大学博士課程理学研 究科数学専攻単位取得退学。理学博士。同年東京 理科大学助手，同大学教授を経て，1998 年 4 月 より慶應義塾大学理工学部数理科学科教授。現在 に至る。応用統計学，データサイエンス，方向統 計学, 離散分布, 多变量解析の研究に従事。
田中 勝 (非会員) 1984 年 3 月慶應義塾大学医学部卒業。

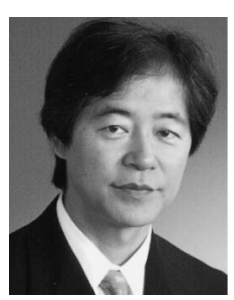
1992 年 3 月医学博士取得。1993 年 1994 年イ ギリス・UWCM 皮膚科学教室留学。慶應義塾大 学医学部皮膚科助教授を経て, 2006 年 1 月より 東京女子医大助教授。 